\title{
一慢性祭不全患者との比較
}

\section{○牧野智恵 （福井県立大学看護短期大学部）}

はじめに：、癌は慢性疾患であり、癌とともに過ごす期間が長いため、「病気とともに過ご しながら、よりよい状態で生活できるように」援助することが癌患者への重要な看護であると 言われている（季羽、1993）。そのため、癌患者の意識調査は多くおこなわれてきた。しかし、 癌患者とその他の慢性疾患患者との意識調査を比較したものはない。今回、癌の告知を受け手 術後の患者と慢性疾患患者との生き方へ意識の比較をし、その特徴が示唆されたので報告する。

研究方法：＜調查期間・対象・方法>平成 7 年 7 月から 9 月の期間中、 F市の総合病院に 入院中の癌患者で手術後体調の回復した時期の患者 26 名に対して, 質問紙による面接調查をおこ なった。慢性腎不全患者に関しては、血液透析療法（以下HDとする）を受けている患者55名、 および腹膜透析療法（以下CAPD とする）を受けてる患者 42 名に対して、平成 5 年に行った調査 結果を用いた。質問紙は、梶田㦒一（1990年）の開発した「生き方意識インベントリィー」を 用いた。このインベントリィーは「自己の存在意義・自己受容」「脱自己中心性」「自己の可 能性・目的」「努力への意志・向上心」「ニヒリズム」に関わる感覚・意識について、5 領域 30項目で構成されている。各質問項目について「はい」「いいえ」「どちらでもない・考えた ことがない」の 3 件法で回答する方法をとった。同時に患者の背景（性別、年齢、職業）につ いて回答を求めた。各質問項目に対し、「はい」と回答した数を、性別、年齢、職業別、及び、 疾患別に $\chi^{2}$ 検定を行った（危険率 $1 \%$ 以下を有意差有りとした）。

調査結果：癌術後患者の性別は、男性19名、女性7名。平均年跉56.7歳（SD=9.8）であった。 HD患者は、男性36名、女性19名。平均年令53.8歳（SD=11.2）であった。CAPD患者は、男性26名、 女性19名。平均年㱓 47.7 歳（SD=10.6）であった。年齢による意識の差の見られたのもは、癌患 者では、「何かにチャレンジしたい」が35歳から65歳に有為に高かった。また、HD患者では、 「自分の可能性を実現させたい」が55歳から64歳にかけて有為に低かった。職業による意識の 差は見られなかった。性別では、HD患者で「努力が大きな成果になる」が男性に有意に高かっ たのみである。疾患別に見ると（図参照）、癌患者が有意に高い意識として、「大きなチャン スがそのうち来る」「何かにチャレンジしたい」「自分のことは考えに入れず実行する」であ った。また、HD 患者が有意に高い意識の項目として、「自分の存在は無意味」であった。

考察 : 癌術後患者の特徴として、告知によって、癌であることを受け入れた上で、「何かに チャレンジしたい」「大きなチャンスがそのうちくる」と、前向きな意識を持っていることが わかった。季羽によると、「ショックから立ち直る」のは、告知後 1 週間から 1 力月以内之言 われている。今回の調査時期が、術後平均 25 日目であったことから、手術により、癌をほぼ取 り除いたと説明を受け、体調も回復したという時期であったことも、この結果の誘因と考えら れる。癌患者に比べ、HD患者は、食事や水分など生活規制が強いため、自分の可能性への意欲 が低下し、人生の無意味感が強くなる。しかし、癌患者の場合も、再発への不安や、症状の悪 
化から、今後、生き方意識に変化が生じることは明らかである。今回の調査結果から、癌患者 が今後前向きな意識で闘病生活を送れるか否かは、術後退院時の関わりに大きく影響されると 考えた。

研究の限界 : 今回の調査は対象者がまだ少なく、一般性として捉えることには限界がある。 今後、さらに調查対象数を増やすとともに、術後 1 年以上の癌患者を対象に調查し、他の慢性 疾患患者との比較が必要亡考える。

参考文献 : 季羽悸文子; 「癌告知以後」、岩波新書、1993.

牧野智恵 : 血液透析療法を受けている患者の「生き方意識」の一考察、福井県立大学看護短 期大学部論集創刊号、1995.

質問項目・領域

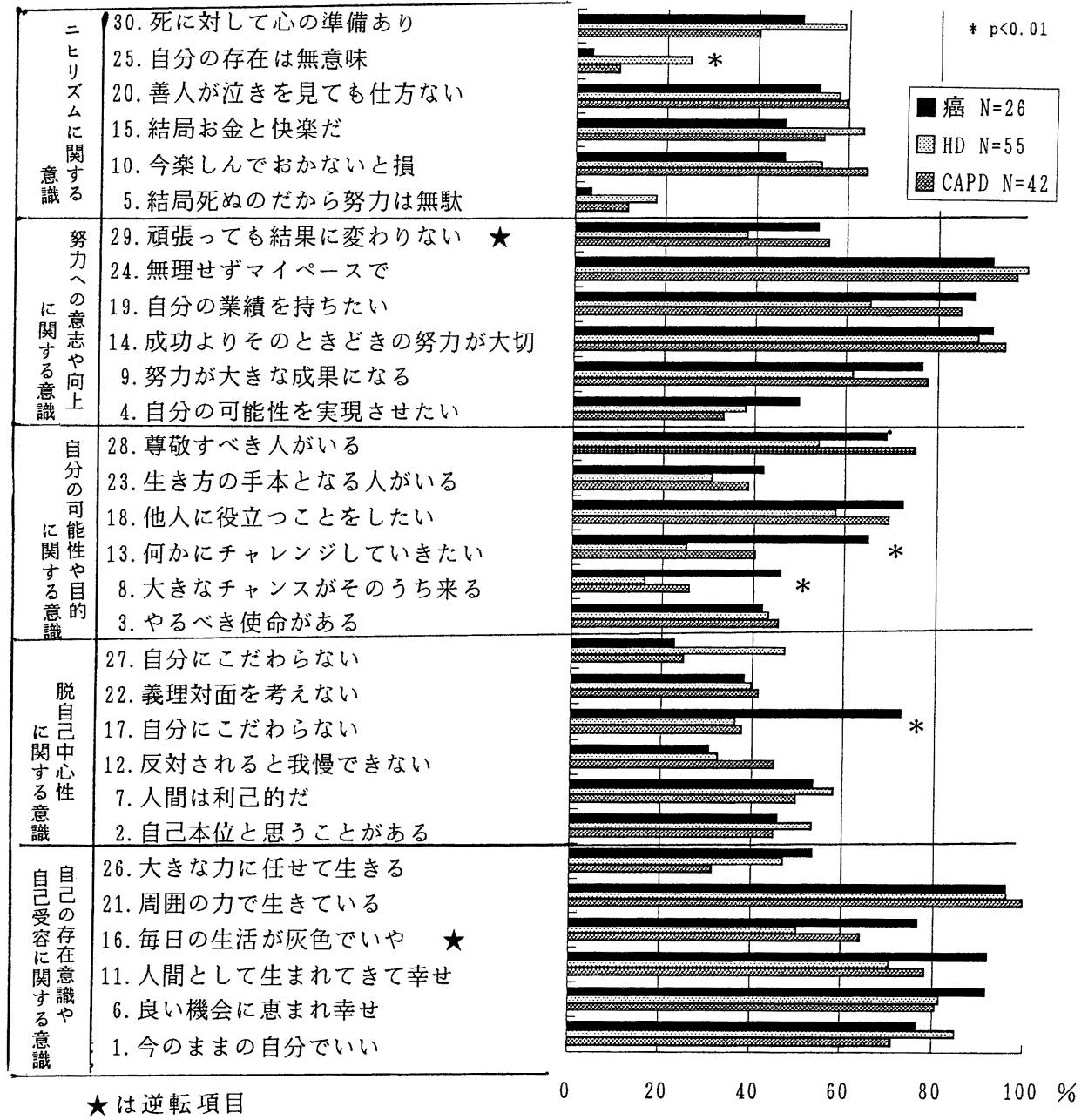

癌・慢性腎不全患者の生き方意識比較 